\title{
建築家 R. マレニステヴァンスの映画セットデザインに関する考察 A STUDY ON THE FILM SET DESIGN OF R. MALLET-STEVENS
}

\author{
阿 部順子*，小林 克弘** \\ Junko $A B E$ and Katsuhiro KOBA YASHI
}

\begin{abstract}
The purpose of this study is to make clear the ideas and practice of Robert Mallet-Stevens, a French modern architect. for the film set design. He designed about 15 film sets in 1920's, some of which are for historical dramas, and succeeded as a set designer. Now simply considered as a person who introduced "modern architecture". into the films, he was one of the leading architects who also introduced the technique of architecture into the film set. The most important of his ideas for the film set is to create the sens of perspective, and he proposed various technical ideas for it.
\end{abstract}

keywords: Mallet-Stevens, film set design, France, 1920's, modern architecture マレシステヴァンス、映画セットデザイン、フランス、1920 年代、近代建築

1. はじめに

$1-1$. 研究の目的

ロベール・マレ=ステヴァンス(1) (Robert MALLET-STEVENS, 1886-1945）は、第一次世界大戦と第二次世界大戦の間に活躍した、フ ランスの代表的な近代建築家の1人で、代表作には、パリ 16 区のマレ ニステヴァンス通りの住宅样（1926-27）、アール・デコ博（1925 年）、 パリ方博（1937 年）のパウィリオン等がある。古典的装斾を排した、白 い箱型の国際核式的な建築に、芸術家によるメタルワークやステンドグ ラス等で独特の優美さを加味したことが特徽である(2)。

建築家として諗知されているマレ=ステヴァンスであるが、1920 年か ら 28 年頃まで、15 以上の映画セットデザインを手掛けている。建築家 としての名声を確立し、実施作品が次々に設計された 1923 年以降も、 快画セットデザインを続けたこと、更に映画セットに関する著述から、 咉画セット自体への強い関心が伺える。また、現契の建築空間に近似し たセットのデザインを手掛ける中で、彼が空間莓成や装飾手法のアイデ イアを得たり、実験をしたりしたであろうことは、十分にありうる事と 考えられ、彼のセットデザインに注目することは、彼の建筑作品の造形 手法を推察する上で重要と思われる。

本稿は、マレニステウァンスの映面セットデザイナーとしての当時の 評価を雑誌等から探し、夷績を明らかにした上で、彼の映画セットの造
形理念を分析・考察することを目的とする。まとまった形で建勧造形理 論を残さなかった、マレ=ステヴァンスの作品研究において、本考察は 別の視点から新たな資料を得て、その造形理念を推察する手掛かりとな るものである。

1 -2. 資料

1920 年代の主要な映画雑誌 ${ }^{(3)}$ フランス映画史、映画セットデザイン に関する著作(4)から、マレ=ステヴァンスの映画セットデザイナーとし ての実績や当時の評判を明らかにした。また、マレニステヴァンス本人 による著作の分析、セットを手掛计た映画の鑑賞を通じて、マレニステ ヴァンスの造形理念を考察した。鑑賞できなかった映画については、写 真資料を参照した。以上の資料収集は、パリのBibliothèque du Film(BIFI)を中心に行い、また BIFI の助言を得て国立映画センター Centre National de la Cinématographie (CNC)、シネマテーク・フラ ンセーズ Cinémathèque Française 老含む主要な映画関連凟料保存施設 に資料の有無を確認した。

\section{$1-3$. 既往研究}

2つのモノグラフのなかで既に、映画セットデザインについては、考 察・言及されている。ミシェル・ルイは、マレ=ステヴァンスの著述を 部分的に取り入れながら、セットデザインを概説した (5)。リュック・ ウタースは、作品リストを提示し、セットデザインを特徵別に、(1) 第
* 東京都立大学大学院工学研究科建築学専攻 大学院生・修士 (工学)

** 東京都立大学大学院工学研究科建築学専攻 教授・工博
Graduate Student, Dept. of Architecture, Graduate School of Engineering, Tokyo Metropolitan University, M. Eng.

Prof., Dept. of Architecture, Graduate School of Engineering, Tokyo Metropolitan University, Dr. Eng. 
表 1 : マレ=ステヴァンスの啌面セットデザイン

\begin{tabular}{|c|c|c|c|c|c|c|c|c|c|}
\hline 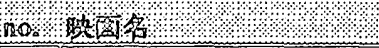 & 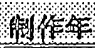 & 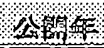 & 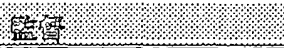 & 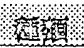 & A & 8 & e. & 10. & 被证 \\
\hline L 1 Le secret de Rosetce Lambert & 1920 & $\sqrt{1920.11}$ & Raymond BERNARD & 国代调 & $*$ & $*$ & * & $*$ & 直 \\
\hline $2 \sqrt{\text { Jettature }}$ & 1921 & $?$ & Gilles VEBER & 代的 & $\sqrt{*}$ & * & \%* & $*$ & 有 \\
\hline 3 Le jockey disparu & 1921 & $\sqrt{1921.12}$ & Jacques RIVEN & 巽代诃 & $*$ & & $*$ & $*$ & 刑 \\
\hline 4 La maison vide & 1921 & 1921.10 & Raymond BERNARD & 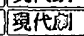 & F & & 2 & * & 然 \\
\hline$5 \longdiv { \text { Les Trois mousquetaires } }$ & 1921 & 1921.10 & Henri DIAMANT-BERGER & 璴史里物 & $*$ & $*$ & * & $\%$ & 峟 \\
\hline 6 Le mauvais garcon & 1922 & 1923.2 & Henri DIAMANT-BERGER & 兾代间 & * & & F & 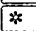 & 有 \\
\hline $7 \sqrt{\text { Triplepatte }}$ & 1922 & 1922.11 & Raymond BERNARD & 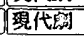 & * & ** & $\sqrt{2 x}$ & $\sqrt{1+}$ & 峟 \\
\hline 8 Vingt ans apres & 1922 & 1922.12 & Henri DIAMANT-BERGER & 魔史物 & \# & & $*$ & * & 䈐 \\
\hline 9 Gonzague & 1922 & $1923.1^{\circ}$ & Henri DIAMANT-BERGER & 㒻代閶 & & & $\sqrt{1 *}$ & & 筲 \\
\hline 10 L'Inhumaine & 1923 & 1924.12 & Marcel L'HERBIER & 兒代面 & * & $\%$ & $*$ & + & 峟 \\
\hline 11 Les costaud des épinettes & 1923 & 1923.4 & Raymond BERNARD & 思他的 & * & $*$ & $*$ & $*$ & 峟 \\
\hline 12 Soeur Béatrice & $?$ & $?$ & Jacques RIVEN & 䔬代䤄 & & & * & * & 栗 \\
\hline 13 Par habitude & $?$ & $?$ & Henri DIAMANT-BERGER & 梘代闻 & & & * & & 有 \\
\hline 14 Jim Bougne boxuer & $?$ & $?$ & Henri DIAMANT-BERGER & 傎代首 & & & $*$ & & 硧 \\
\hline 15 Le miracle des loups & 1924 & 1924.11 & Raymond BERNARD & 整史物 & * & 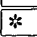 & $*$ & F & 有 \\
\hline 16 La rond de nuit & 1925 & 1925.11 & Marcel SILVER & 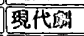 & * & i & $*$ & * & 南 \\
\hline 17 Le vertige & 1926 & 1926.7 & Marcel L'HERBIER & 翼代后 & * & क & $\not$ & $\%$ & 䈐 \\
\hline 18 Princesse Masha & 1927 & $\sqrt{1927.10}$ & René LEPRINCE & 畏代閶 & $*$ & * & $*$ & $*$ & 楠 \\
\hline 19 La sirène des Tropiques & 1927 & 1927.12 & H.ETIEVANTR B N NALPAS & 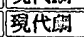 & & 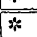 & & & 㤢 \\
\hline 20 Le tournoi dans la cité & 1928 & 1929.2 & Jean RENOIR & 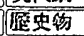 & $*$ & it & * & $\%$ & 䈐 \\
\hline 21 Les mystères du Cháteau du Dé & 1929 & $?$ & Man RAY & 玨代笽 & & & & $*$ & 䈐 \\
\hline
\end{tabular}
田典 :

A. Cinémguthèque de 'loulouse, Catalogue des films français de long métrage, films de fiction 1919-29, 1984

B. International Fedention of Film Archives (H'LA'), International Directory of cinematographers, set-and costume, designers in Film, vol.2 France (from beginnings to 1980)

C. Kobert Mallet-Stevens, Le décor au cinéma, Edition Séguier, Paris 1996

1). Luc WOU'I'ERS, "Cinema and Architecture", Rob.Mallet-Stevens, architecture,furniture, interior design, Hirst MI'T Press, Massachusetts 1990

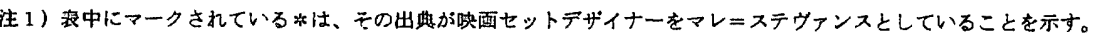

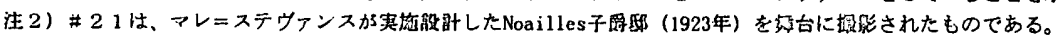

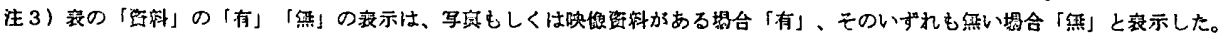

一次世界大路後のサロン・ドートンヌ Salon d'Automne のスタイルに近 いセット(1920-22)、(2)キュビスト・セット(1923 年の「人でなしの女 L'Imhumaine 」、1926 年の「目眩Le Vertige」が該当)、(3) 檚史劇の セット、と3つに分穎した。特に「ロゼット・ロンベールの秘密 Le secret de Rosette Lambert」(1920)、「人でなしの女」、「目胘」に注目し、 デザインの影䜾源等も洘察し、既往研究の中では最も詳しく重要なもの である ${ }^{(6)}$ 。

しかし上記の 2 者では、マレ=ステヴァンスの著述について、言及は されているものの、詳緗な分析・例示はなされていない。また、マレ= ステウァンスのセットデザイナーとしての活動の背景や、その評価は十 分に述べられていない。他には上記の 2 者を主たる参侾立献とした概説

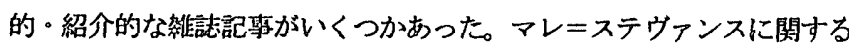
最も詳細な論文(7)の中でも、欥画セットデザインについては、 5 作品を 挙げるにとどまり、全体倠は提示されていない。これらの既往研究は、 複㶿の CD-ROM とデータベース ${ }^{(8)}$ を用いて梌索した。

2. セットデザイナーとしての寒緼

$2-1$. 背昌

マレニステヴァンスが映画セットを初めて手掛けたのは 1920 年と吉 われており、ちょうど第一次世界大戦によって、アメリカに制作数で大 きく遅れをとったフランス映画の、復活の気通が高まってきた頃である。 第二次世界大戦以前からセットデザイナーとして活躍していたレオ ン・バルザクは、「外国一の貼路をほとんど完全に失い、自国内におい て非常に㮹位な立場を占めるアメリ力映画との竸争で、フランス映画の 生き残る道仙ひとつしかなかった。それは価値のある立派な作品をつく ることである」 ${ }^{(9)}$ と、この状況を振り返っている。質の高い映画のた めに、臯割の背景にかわって建て込みセットの需要が生じてくるにつれ、

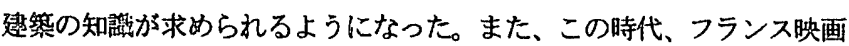
界では、第一次世界大戦によって人材の入れ替わりが起こり、建築家や
室内装飾家、現代劇の舞台装置家といった新しい人材が、映画セットデ ザインに流入しや寸くなっていた。1921 年には、一部の若い映画監督、 美術家、音楽家、詩人たちによって、映画を絵画・彫刻・詩・ダンス。 音楽・建筑を統合した第 7 番目の芸術として盛り立てて行こうとする団 体「第 7 芸術愛讙者クラブ Club des Amis du Septième Art (CASA)」 も設立された。

2-2. 暞画セットデザインに䦭わり始めた玨由

マレニステヴァンスは、第一次世界大戦中 1914 年から約 2 年半、空 軍で航空観察写真撮影を任務としていた。戦後、初めて映画セットを手 掛けるまで、建築実施設計の仕事はなく、室内装飾の仕事や展覽会への 参加・雑誌への寄稿といった活動をしていた彼にとって、映画セットデ ザインは、まず、表現の場を得ることであった。

さらに、「よく理解された映画は、展臨会、それがどれほど頻察に 通われたとしても、それよりはるかに㑑れたプロパガンダの道具である に違いない」(20)という発言から、映画セットを通じて、大衆に、自ら が信じる近代建築を啓蒙しようとも考えていたことがわかる。

そして、先述のCASAにも設立メンバーとして加わっていたことか ら、「新しい芸術としての映画」への関心も大きかったことがかかる。 また、展覧会等で提案していたインテリアデザインというものと、映画 セットのデザインは遠い関係のものではない。マレニステウァンスにと って、新しくそして既存の芸術を統合する意義を持つ「映画〕への参加 は、自然の成り行きであったのだろう。

\section{2-3. 手通叮た㬇画它ット}

手掛けた映画セットの正確な数は不明である。第一次世界大戦からト 一キ一映画が登場する 1929 年までの、フランスの長編フィクション映 画の $70 \%$ \%゙失われていること、またこの時期、一般に映画セットデザ イナーの名は重要梘されておらず、記録が不十分であったこと(1')から、 マレニステウァンスの作品の完全な作品の把暒は不可能である。表 1 に、 
表 2 : 映面に関する著述

\begin{tabular}{|c|c|c|c|c|c|c|c|c|c|}
\hline No. & $8,1.15$ & 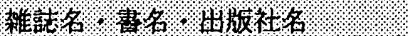 & 81. & 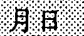 & s: & (1) & (2) & (3) & (4) \\
\hline 述 1 & Le noir et blanc & Tekhnè, lère année & 1911 & 16-Nov & no34 & & $*$ & & \\
\hline 2 & $\begin{array}{l}\text { La décoration moderne au cinéma } \\
\text { par Emile Seyden }\end{array}$ & L'Art et les artistes & 1921 & Oct & no20 & * & & * & \\
\hline$\overline{3}$ & $\begin{array}{l}\text { Le meuble moderne au cinéma } \\
\text { entretien de Félix Fénéon }\end{array}$ & $\begin{array}{l}\text { Bulletin de la vie artistique } \\
\text { Galerie Bernheim.Jeune, Paris }\end{array}$ & 1922 & 01-Mar & $?$ & * & * & * & \\
\hline 4 & Le cubisme au cinéma & Comoedia & 1923 & 08-Jan & - & * & * & * & \\
\hline 5 & Les décors au cinéma & Gazette des Sept Arts & 1923 & 25-Jan & no2 & * & & & \\
\hline 6 & Archilecture, les cinémas & $\begin{array}{l}\text { Catalogue de l'Exposition de l'art dans } \\
\text { Je cinéms fiangais, Musée Galliera, Paris }\end{array}$ & 1924 & - & - & & & & * \\
\hline 7 & Le cinéma et les arts. L'architecture & Cahiers du mois & 1925 & $?$ & no16-17 & & & * & * \\
\hline 8 & Le décor au cinéma, Introduction & $\begin{array}{l}\text { Le décor moderne au cinémg } \\
\text { Charles Massin \& Cie, Paris }\end{array}$ & 1928 & - & - & * & & & * \\
\hline & $\begin{array}{l}\text { Le décor, Conférence donnée au } \\
\text { Vieux.Colombier en } 1926\end{array}$ & $\begin{array}{l}\text { L'Art cinématographique 6, } \\
\text { Librairie Félix Alcan, Paris }\end{array}$ & 1929 & - & - & * & & * & * \\
\hline
\end{tabular}

注 1) 表中の(1)、(2)、(3)、(1)の瀵は本文中の内容」の番号に一政し、それらの内容が各著述に書かれている坦合、*で示した。

注 2) 既往研究では、M. Lou isが (述7,8,9) を、L. Houtersが (述1, 2,7,9) と、"L'architecture et le décor de théâtre", Tekhnè, pp.339-340,1911を奇文献としている。 注 3）雑誈名には下線をひき、整名は斜体で示した。

䙡数の資料出典から、彼が手掛けたとされる映画セットを示す。

これらの映画の、マルセル・レルビエ Marcel L'Herbier (1888-1979)、 レイモン・ベルナール Raymond BERNARD (1891-1977)、アンリ・ ティアマン=ベルジェ Henri DLAMANT-BERGER(1895-1972)、ジャ ン・ルノアール Jean RENOIR (1894-1979) は、フランス映画史の中で 重要と評価されている監督たちである。

これらの 21 作品のうち、4作品は「歴史物」であり、セットにも「近 代」を連想させるものはみられない。例えば「三銃士 les Trois Mousquetaires」では、莫大な保険料を払い、物語の時代の家具を借り 出したり、正確なコピーを制作寸るなどセットがその時代に完全に忠実 であるよう努力が払われた(22)。

\section{2-4. 映画セットデザイナーとしての評価}

今日、映画セットデザインに閵する著作、雑誌記事の中で、マレ=ス テウァンスは概ね、単に「吷画に近代建管を遒入した人物」と紹介され ている(13)。これは、(1) セットデザイナーというより、彼がまず、近代 建築家としてより有名であること、(2) 現代劇咇画で、サロン・ドート ンヌ等の展筧会、雑誌などに発表してきた建築家・室内装飾家としての 作品と同様のものを、映画セットに使用していることから下された評価 であろう。しかし、この現在の評価は不十分であり、以下に補足する。

まず、マレ=ステウァンスは「フランスで先駆的に映画に参加した建 築家の一人」であるとも承える。というのも、彼がセットデザインを始 めたのは 1920 年頃で、1921 年秋には既に、『芸術と芸術家』という美 術誌の「映画における現代的装飾」という特集記事の中で、実践してい る映画セットデザインの考え方の総括を依頼されるほどの活躍ぶりで あり (14)、建築家や空内装飾家が映画セットデザインに新たに殺到して きたのは 1922 年以降 (15)だからである。

第一次世界大戦前は、剧場のセットのような、画家が制作した書割の セットが使用された。建て込みのセットは、1914 年のイタリア映画「カ ビリア Cabiria」（ジョウァンニ・パストローネ監督、美術監督不明） で初めて既に大成功を収めた (18) とはいえ、1920 年代はじめフランスで は「相变わらず書割は存在していたし、それは徐々にしか姿を消して行 かなかった。べニヤ板の枠でセットがよく作られ始めたのは 1926 年頃 にすぎない。この封代までは（洔としては、そのあとでさえも）スタジ オのく在庫道具リスト>のなかのものをつかうことに留まった。 .....
(中略）....シナリオのために特別に考えられたセットをつくるのは、 くうるさ型〉監督が撮る映画のためだけで、ほかの監督のばあいは、先 にみたように、その映画に多少とも適したく在庫道具リスト〉を使うこ とで我僈していたのである」(17)という状況であった。よって、単に「近 代建築を導入した」という以上の「建築家の感性、技術も導入した人物 の一人」と言ってもよいだろう。

そして、当時のマレニステウァンスのセットデザインは概ね、当時非 常に高い評価を受けていたということがわかった。最初の映画セット

「ロゼット・ロンベールの秘密」では「セットデザインの興味樑い試み が、R. マレニステヴァンスによってなされた。彼は才能とセンスをも つが、スクリーンのく白と黒〉は＜黒と白〉の方法によって得られるに 違いないということを信じるという誤りも同時にもっている。しかし被 は、その誤りから覚めるだろう。私は確信している」と批評されながら も、一人のデザイナーが一つの映画全てをデザインする久点として「全 てが同じ家具の中で、同じ環境の中で、起こっている印象を与え」、「デ ザイナーの重要性が演出家のそれの妨げとなる」という批判を、「これ は演出家の問題」としながらも加えられている(18)。

これ以降は、「これは人を引き付什る作品である。その多様なセット デザインのおかげで、チャーミングなディテールにおける、そのプロッ トのおかげで」 (19)、「...セットはロベール:マレ=ステヴァンス氏に よってデザインされた。豪華な家具はセットをエスコートし、その芸術 的価値を一層高める。センスのよさ、プロの技術と完壁な演技面への配 庶は、その研究とこの結果の獲得を思うままにした」(20)というように、 マレ=ステヴァンスのセットデザインはそれぞれ高い評価を受けている。 歷史物映画のセットデザインも「セットは非常に入念になされている。 それは最も希な才能をもつ芸術家ロブ・マレニステヴァンス氏に㷌すべ きものである」(21)、「....ベルジェ (監督) は、セットと衣装において、 真の入念な芸術的な作品をここで成した」(22) とおいうように高く評価 され、特に「三銃士」と「狼の奇跡 Le Miracle des Loups」では、商業 的にも大成功を収めた。年成功の度合いは「その成功は電慗的である。 二度とないだろう。フランスで、ひとつの映画がそのように受け入れら れることも、そのように奇跡的な収益を達成することも」(23)。「『狼 の奇跡』は、フランス映画史上初めてパリのオペラ座で上映される特権 をもった」(24)といった記述によく表されている。これらの記述から、 


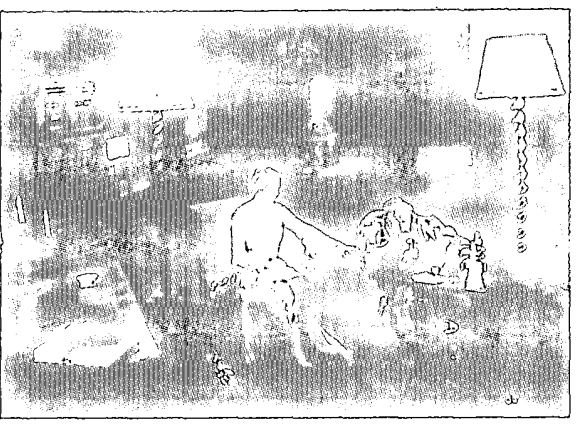

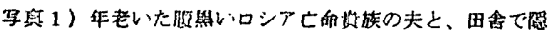

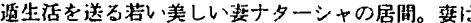

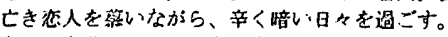

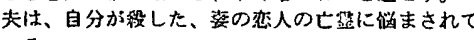
いる。

成功したセットデザイナー」であったとも言える。

3. 著述の分析とセットとの相閶

表 2 の胦画に関する渚述を対鱿に、内容を分析した。その結果、内 容は、大きくは、(1)映画セットのあり方を述へたもの、(2)造形について 述べたもの、(3)具体的なテクニックを述べたもの、(4)建築に関して述べ たもの、といった4つに分類できた。本研究はマレニステヴァンスの映 画セットデザインの考察を目的とするため、(4)の建築に關する部分は、 㬂画セットと建筑デザインの相関を考察する別稿の中で扱うをのとし たい。 以下、(1)(2)(3につて、マレニステウテンスの考え方をまとめ、 そ㧈がセットにどのように現㧈ているわ述べる。以下の「」の後の（述 1）といった表示は、表 2 中のどの舶述から引用したのか示す。

\section{3 -1. 㬈画它ットのあり方}

マレニステウァンスにとって、映画のセットは、㓺場のそれとは異な り「設計図のように設計される」(述 3)ものであり、特殊な場合を除いて 「セットデザイナーは、より現実主㐨でなけれぱならない。もしセット デザイナーが、玄関ホールを表現しなければならないなら、玄関ホール を設計し、建設させなけ放ばならない(述9)とし、リアリストであるこ とと、建築家らしさが伺える。

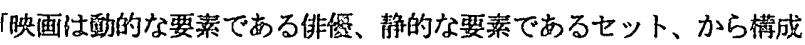
される」(述9)と、吹画におけるセットの役割を、たくさんの楬成要案の 一つのそれというより、もっと重要なものと捉えていた。俳優を担当す る演出家と、セットを担当するセットデザイナ一について「(両者は) 絮密に協候しなければならない。前者 (演出家) は人生を創造し、後者 (セットデザイナー) は人生の枠をつくる」(述 5)と述べていることから も、同様の彼の意識がわかる。

このようにセットの役割を自負していたマレニステヴァンスにとって、 セットも「《演技》しなけれぱならない(述 9)のであった。《演技》 とはつまり「見るやいなや、どんな人物がそこに住んでいるのかかかる ように、咉画セットを組み合わせること」(述 3)であり、この考え方は、 セットデザインを乎掛けていた間、一賷していたものと考えら机、「(セ ットは）登場人物を位置つけ、同様にその動作を説明することに貢献 る、ある特定の㭙代の体組である」(述 5)、「セットは登場人物の社会的 状況、趣㙅、習慣、生き方、個性を示さなければならない(述9)といっ た言藥にも示されている。

このような《演技》は、画面に咉る全てのもので成し遂げられるもの であった。家具や小道具、それらがとても個性的だとしても、登場人 物を連想させるには十分ではない。その部屋の形热、ウォリューム、突 出部や浬みは、統一感を形成するために、家具のディテールと調和しな
け扎ばならない。セット、調度品、衣装は映画の中で役割を担う。映画 の一コマーコマは、俳候の演技とともに、それらを固定する。だから完 壁な調和、完壁な連絡が必要なのである」(述 9)。「セットを創造するの は、カーペットや、いくつかのクッション、カーテン、フリルのついた 服装や、よろい戸ではない。小道具のクオリティ、オリジナリティ、美 しさがどうであれ、それらはセットを構成しないり(述 5)。「(モダンス タイルのセットの場合なら）家具無しに、芸術作品むひとつもなしに、 セットはモダンでなけ狄ばならない。セットはその形態によって、シル エットによって、ヴオリュームによって、モダンでなければならない (述 5)。

䈉者が映画全体を蓝賞し得た 表 1 中の 映画、（映 6、9、10、15、 17、19、20、21）について、インテリアを担当していない（映 10）と、 設計した建築が後に映画の舞台となった（映 21）を除いて、登場人物の 住居が、その人物の性格、社会的地位、精神状態を描き出すといった、 セットへの意図は明解に読み取れた。また、時代考証の拘束を受けない 分、現代劇のほうがより鮮明であった。ここに一例を挙げる。

(例) 17 「目眩Le Vertige （1926 年）（写真 1、2、3） 不幸な結婚生活を送るロシア人亡命悬族の夫婦の住まいは、だだっ広 く、天井は高すぎ、家具は少なく、照明も少なく、空も小さい。ひたす ら陰穊なつくりである。エキゾチックなロシア風の装飾がついた大きな 家は、その家の主人の故郷へのノスタルジアと共に、亡命先のフランス での生活になじめない頑なさを描いている。主人公のアンリの家はダイ ナミックな直線で楧成され、ドローネ夫妻、P.シャロウらの前衛芸術 家による絵や調度品で满たされている。自動ドアまであり、快適で裕福 な「現代的」な生活が読子取れる。セットは「現代の」ヒーロー像を呈 示ずる。アンリの母の家の居間は、フリルのついたンファー、ドレープ カーテン、花柄の壁紙等、母の衣装も含めて、裕福さと居心地の良さ、 紐々した女性らしさにあふれている。母と息子のガウンはそれぞれ、前 者がポール・ポワレ風、後者がドローネー風と、三人の世代の違い、好 みの違いをはっきりと示す。

他の登場人物についても、シナリオが要求する個性に応じて、場所に よって、セットは徹底的に《演技》している。これらのセットが、この 映画に大きく貢献していることは確実である。

$3-2$. 造形

造形に関しては、以下の 2 点が最も特徵的な考えおよぴ、手法である。 策何学的な穆、硬い線」

「カリガリ博士の箱 Das kabinett des Doktor Caligari」（1919 年、ド 信、ロベルト・ウィーネ監督) のセットについて、マレニステヴァンス 


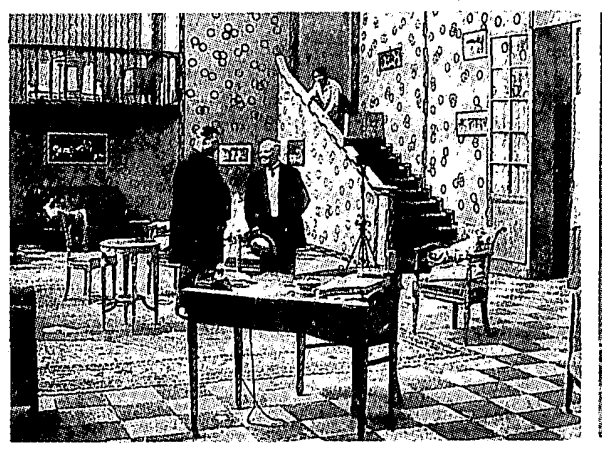

写点 4)「绿肘り」の例 階段や政等に「栐攻り」が施されている

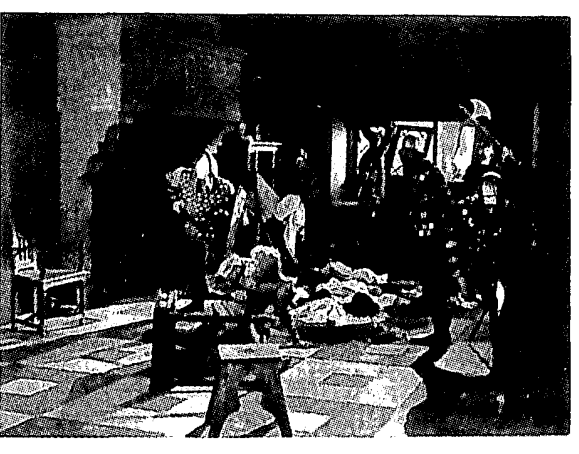

军其 5 )「幾何学的な被」の例：林のパターン

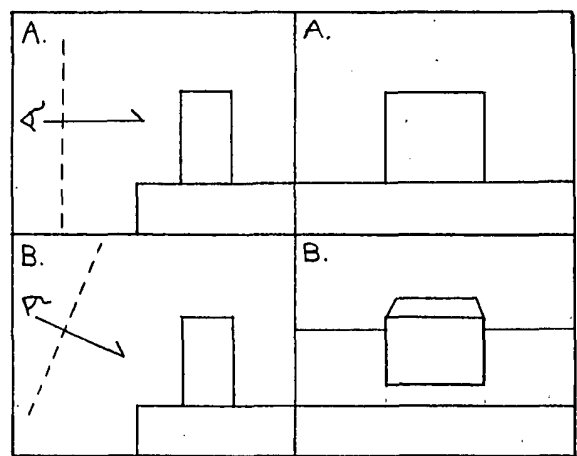

图1) カメラポジションと立体感

A. 木平なカメラポジション

B. 高いカメラポジション
は「確かに興味哚い胦画だが、咉画とは逆のものである」(述 4)とし、後 には「失败であった」(述9)と絬諭づけた。彼がキュビスト・セット(2s) に基本的には批判的だったのは、「登場人物の表現の効果を害しうる、 読みつららい、混乱した背景を避けよう」(述 4)という考えがあったからで ある。「(キュビスト・セット等では) 俳優はパズルのバラバラのかけ らの前で㴼技する。私達は俳優を一枚の方眼紙の前で演技させる」(述 4) という婙えは、整然としたセットへの志向をよく示している。

これを害現するために、彼は「幾何学的な線、硬い線」の必要性を強 調し続ける。「至るところに、シンプルな、その上硬い線を。俳優の演 技は助長されるだろう」(述 3)、焦淔線、水平線、幾何学的なカ一ブ、 数学的な線は、自然のなかでは非常に希にしか見出されない。それらは 焦明な対立、人物像とのアンチテーゼを強調する。女性の輪郭線と木の 枝の閒に、相似点は何一つなくなるだろう」(述 4)、「俳優の演技を可能 にする、かなり硬いシンプルな線を偨そう」(述 9)。動的要素である俳優 の輪郭 (有機的な線) と、静的要素であるセットの輪郭（幾何学的な線） の鮮明な対立によって、見やすく、わかりや嘫像を得られるという、 この考え方はセットで、例えば床に幾何学的なパターンを用いるという 方法 (写真4) に現れている。また、幾何学的な線をシンプルに組み合 わせることは、パースペクティウのコントロールを容易にし得る。マレ ニステヴンスがセットデザインをしていた時期は、映画はまだほとん ど、モノクロで㫮声であった。見やす寸さわかりや寸さは、非常に重要 であり、「幾何学的な線」はそのための手段でもあったと思われる。

\section{「緑取り」}

1911 年の著述「黑と白 Le noir et blanc」（述 1) の中で、「白い空 間を対照的な黒で緣取ることで、白をより踙かせ際立たせよう」という 考え方が示されている。表 2 中の 1920 年代の著述には、この考えは示

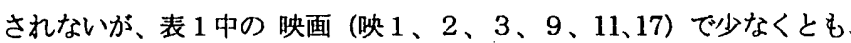
その使用が琶められられることから（写真 5)，この「縁取り」は、マ レ=ステヴァンスのセットデザインのお気に入りの造形手法の一つと 考えてよいだろう。この緑取りは、装飾的な効果もあるが、同時に建筑 物の輸部線を際立たせ、セットの立体感の㓣造に寄与する。この「縁取 り」の带の柄には、縄目模様や市松模様といったバリエーションがある。 $3-3$. テクニック

具体的なテクニックへの言及は、表 2 中の（述 $2 、 3 、 4 、 9 ） に$ 繰り返し みられ、その関心の対象、テクニックの内容は、(述9)がもっとも詳 しいが、各著述の間で、基本的に相違はない。これらのテクニックのお か心か、資料之した胦画や写真の中に、パースや立体感の不自然さやわ かりにくさを感じさせるものはなかった。以下に、テクニックへの言及
を内容別に整理し述べる。

「立体感の創造」(述 $2 、 3 、 4 、 9)$

撮影スタジオの全方向から来る照明による、被写体の映像の平板化を指 摘し、損なわれた立体感を復活させるために、以下の 3 つテグニック を提案している。

(1) 影の强調：影になる面を他の面より醇く法ること（但し、光源の位 置は撮影中、固定しなければならない。物体から生じた影を塗っ ておくこと（但し、登場人物はその影の中を通り過ぎてはいけない。 (2) カメラポジション: 観察者が、地面の上にカットのデッサン（物の 配置）を読み取れるように、かなり高い視点から撮影し、セットの 地面でカットを切り取ること（図 1)。

(3) 視線の留め: 円柱、木、柱、シャンデリアといった視線をとめるも のを手前に配置すること。

「セットの色」(述 $2 、 3 、 9)$

当時はモノクロであったので网色の色調でしか、調和のとれた、諭 理的な収鍐を得ることはできない(述 2)、「緑と赤は黒になり、青は白 になる。私は、ある撮影所で緑の壁のセットを見た。赤い屝が壁の中央 を激しく切断していた。さて、画面では、その郝は完全に消えていた。 開口のない滑らかな表面だけが残っていた。俳優は外に出るために、城 塞の穴を開ける様であった」(述 2、9)。このほかにも、(述 3、4) で もセットを灰色に洷る事を強調している。さらに、セットの色と俳優の メイクの間の関連の必要を指摘している（述 3）。

「パースの効き過ぎへの対策と利用」(述 2、3、9)

(1)実際より小さすぎに見えるので、家具を奥に置かないこと。 (2)非骖の演技をしやすくするために、家具を少なくすること。

「絵西、据刻」(述 3、9)

芸術作品と生きている人間の閒の相違を明白にするために、自然の形 に合致し過ぎた絵や彫像をさけること。

結.

マレニステヴァンスは、セットが映像の「見やすさ・わかりやすさ」 に奇与することを強く意図していた。これを獲得する造形上の手段が

「立体感の創出」であり、これが彼の映画セットデザインの最も重要な 理念である。この立体感によって、観客は明確に画面の内容（俳優の動 きとその背景）を把握でき、画面は生き生きとしたリアリティ、自然な 視界を供することが出来る。第一次世界大戦以前の、固定されたカメラ とだまし絵の書割のセットによる、劇場の舞台と観客の固定した関係を 維持したままの映画（例えばジョルジュ・メリエス Georges Méliès (1861-1938) の映画) にはない、より進化した咉画に対する理解がマレ 
=ステウァンスにはあったといえる。さらに、立体的な建て込みセット であっても、モノクロで然声で画質が現在のそれよりはるかに劣ってい る当時の映画においては、背景をただリアルに哣華につくるだけでは

「見やすさ・わかりや寸さ」は得られない。マレニステウァンスはそれ を理解し、計算し、セットを㔍成した。

以上の分析・洘察から、マレニステウァンスは、映画セットに「建筑 家の副業」としてではなく、椣めて真剣に取り組み、セットデザイナー としても十分力量を発揮したといえよう。

注.

1) 従来、この建築家の名のカタカナ表記はマレニステウァン、マレット= スティーウンス等と一定していなかった。フランスの Institut Français d'Architecture (IFA)に発音記号を求めたところ

IMA LE STE VE⿱ S S』という回答を得た。また、係である Catherine GILBERT 氏にも発音を確珰した。本稿の表記は、この原音 の発音を近似した日本語に郘き换えたものである。

2) フィリップ・ションソンによる1932 年の「インターナショナル・スタ イル」には、マレニステウァンスの作品は形態的には的箱型をしてい るが、含まれていないため、本䅻では国際㧼式的」とした。マレニス テヴンスと「国祭様式」については別稿で考察する。

3) フランスの映画批評史の矿究密である、Michel CIMENT, Jacques ZIMIMER, La Critique de cinéma en France, Ramsay, France, 1997

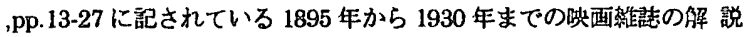

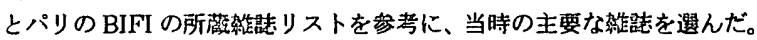

4) 考にした主器な媩として以下のものがある。 マレニステヴンスの籍作缺

-- Robert MALLET-STEVVNS, Présentation d'Odile VAILLANT, Le décor au cinéma, Nouvelles Editions Séguier, 1998 pour la présente édition

フランス旁面农にっいて

- Jean-Pierre JEANCOLAAS, Histoire du cinéma français, Edition Nathan, Paris 1995

- Jean-Louis LEUTRAT, Le cinéma en perspective: une histoire, Edition Nathan, Paris 1992

- Claude BEYLIE, Jacques PINTURAULT, Les Maitres du du cinéma français, Bordas S.A., Paris 1990

セットデザインについて

ーD. アルブレヒト著、获 正勝 郡『デサインンク・ドリームスー 映画に見る近代建築』（SDライブラリー17、鹿島出版会、1995 年) 原著は Donald ALBRECHT, Designing Dreams-Modern Architecture in the Movies, Thames\&\&Hudson, London 1987

- Eric MYERS, Howard MANDELBAUM, Screen Deco, Columbus Book, England 1985

- Charles AFFRON, Mirella Jona AFFroN, Set in Motion-Art direction and Film narrative, Rutgers University Press, 1995

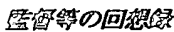

- Marcel L'HERBIER, La tête qui tourne, Pierre Belfond, Paris 1979

- Pierre LHERMINIER, Cinéma d'aujourd'hui 78 :Marcel L'Herbier, Editions Seghers, Paris 1973

- Jaque CATELAIN, Jaque Catelain présente Marcel L'Herbier: les grands créateurs de films, vol.1, Editions Jacques Vautrain, Paris, 1950

- Jean RENOIR, Ma vie et mes films, Flemmarion, Paris 1974

- Raymond BERNARD, André LANG, Les Mémoires de Raymond Bernard, Société des Auteurs et Compositeurs Dramatiques, Paris 1980

疑西リストについ

- Catalogue de Exposition organisée par le Centre National de la Cinématographie et le Conservatoire National des Arts et Métiers Image \& Magie du cinéma français-100ans de patrimoine
- Fédération Internatinale des Archives du Film( FIAF), 1938 1988: 50as d'Archives du Film, FIAF, Bruxelles 1988

5) Michel LOUIS, "Millet-Stevens et le cinéma 1919-1929", Rob.MalletStevens architecke, Editions des Archives d'Architecture Moderne, Bruxelles 1980, pp.123-142

6 ) Luc WOUTERS, "Cinéma and Architecture", Rob.Mallet-Stevens, Architecture, Furniture, Interior design, Jean-François PINCHON's direction, First MIT Press edition, Cambridge, Massachusetts 1990,pp.91-107 原著はフランス語版、Rob.Mallet-Stevens, architecture,mobiler,décoration, Philippe Sers Editeur, Paris 1986) これ以外に、同管者の重要な参考文献として、Luc WOUTERS, "Rob.Mallet-Stevens, Cinéma: vous avez dit architecture? A propos d'une exposition", POSITIF, no.310, déc. 1986, pp.17-20 がある。

7) Cristian BONNEFOI," Rob.Mallet-Stevens; positions et contradictions de l'architecture internationslen ${ }^{n}$, Thèse de doctorat,

Univ. de Paris I, 1974

8) CD-ROM : International film archive, Film index international, Art Index, CDMarc bibliographie, Répertoire d'art et d'archéologie, Repère, Disertation Abstracts, Doc-Thèses, Inder to theses, Architectural publication inder の他、10 以上の CD-ROM を利用した。 データベース : Françis, Avery Index

9) レオン・バルサック、『映画セットの壁史と技街』（晶文社、1982 年） pp.67-68 (原著は Léon BARSACQ, Le décor de film: Préface de René CLAIR, Seghers, Paris 1970 )

10) Robert MALLET-STEVENS, "Le cinéma et les arts. L'anchitecture", Cahiers du Mois no 16/17, Emile-Paul Frères, Paris 1925, pp.95-98

11) Catalogue des films francais de long métrage: films de fiction 191929, Cinémathèque de Toulouse, 1984

12) "La ville et les arts, cinéma", Paris-Midi, 14 sep, 1921 13)アルブレヒト、前掲瑟 p.83、バルサック、前揭蓄 p.78、Luc WOUTERS、

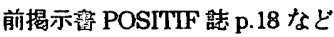

14) "La décoration moderne au cinéma", L'Arts et les artistes no.20,oct 1921

15)レオン・バルサック、前揭書 $\mathrm{p} .68$

16)D. アルブレヒト、前揭䔦 pp. $62-64$

17) レオン・バルサック、前揭落 $\mathrm{p} .68$

18) Louis DELLUC, "Cinéma: Présentation de Le Secret de Rosette Lambert", Paris-Midi, 26 octobre 1920

19) WISBY, "Le jockey disparu” , Le cinéma et l'écho du cinéma réunis, 9 décembre 1921

20) J.TREBOR, "Le Mauvais Garçon", Paris-Midi, 15 décembre , 1922

21) O.REOL, "Les Trois Mousquetaires", Le cinéma et l'écho du cinéma réunis 9 septembre 1921

22) Film Daily, "Comment les Américains ont présenté Les Trois Mousqutaires", La Cinématographie Francaise, no.225, 24 fév 1923, p.24 マレ=ステウァンスはこの映画では长装も担当している。

23) Henri DIAMANT-BERGER, II était une fois le cinéma J.C.Simoen, Paris 1977, p.\$0

24)レオン・バルサック、前掲䉥 $\mathrm{p} .78$

25)「カリガリ博士の箱」はドイツ表現主㲔 l'expressionisme 映画の代表的な 作品であるが、本稿ではマレニステヴフンスの記述のまま訳した。 写点出县 (繁䎐瀻)

写真 1,2 ,3) 映画「Le Vertige」、BIFI 所藏、権利者 Míme.Marie-Ange L'Herbier

写真 4) 映画「Le Mirscle des Loups」、BIFI 所薜、簿利者 Gaumont 社 写真 5）映画「Jockey Disparu」、注 4 前揭樭 P.221

躈辞

本稿の资料閱㹂・収集にあたって、BIFI、CNC の方々には極めて冝重なア ドバイス、ご協力を頂いた。また、故 Marcel LHERBIER 監䝳の令蜶 Mme.Marie-Ange L'HERBIER Gaumont 社は当時の写真を提供して頂いた。 ここに厚く礼申し上げたい。 